\title{
Participatory Management Issues in U.P. Alkaline Land Reclamation Project
}

\author{
Arvind Kumar Singh ${ }^{1 *}$, A.K. Singh ${ }^{2}$, Anurag $\operatorname{Singh}^{3}$ and Rajmani ${ }^{*}$ \\ ${ }^{1}$ Department of Agricultural Extension, Chandra Shekhar Azad University of Agriculture and \\ Technology, Kanpur, Uttar Pradesh -208002, India \\ ${ }^{2}$ Agricultural Extension, Indian Council of Agricultural Research, New Delhi - 110012 India \\ ${ }^{3}$ Sam Higginbottom University of Agriculture, Technology and Sciences, Allahabad, \\ Uttar Pradesh, India \\ *Corresponding author
}

\section{A B S T R A C T}

\begin{tabular}{|l|}
\hline K e y w o r d s \\
$\begin{array}{l}\text { Soil, Water, Rural, } \\
\text { Project, } \\
\text { Management. }\end{array}$ \\
\hline Article Info \\
\hline $\begin{array}{l}\text { Accepted: } \\
\text { 19 July 2017 } \\
\text { Available Online: } \\
\text { 10 September } 2017\end{array}$ \\
\hline
\end{tabular}

Keywords

Soil, Water, Rural, Project,

Management.

Article Info

Accepted:

Available Online:

\section{Introduction}

In Kenya catchment approach (or area concentration approach) with emphasis on community participation in planning, implementation and evaluation was introduced to accelerate implementation of soil and water conservation. Subsidies were removed and resources were allocated to extension, training, tools and farmer trips. Local communities are now more fully involved in analyzing their problem and decision and recommendations are made with their active participation. Community participation is achieved through interaction with farmer by planning teams, formation of Catchment committees by farmers themselves and training through field days, and demonstration tours.

Land care is a significant social movement in rural Australia in which more than 2000 community groups involving one third of all Australian farmers have been formed to tackle environmental problems.

These land care groups are formally linked to existing institutions, including national level policy makers, forming a unique partnership between community and government. Land care group is a group of usually rural people who have come together voluntarily to co- 
operatively tackle environmental issues and develop more sustainable systems of land management. Regular activities of the group include developing a Catahment or district plan which identifies land degradation problems, discusses the challenges of achieving sustainability in the local context and sets out a co- ordinated approach of implementation, facilitating development of individual property plans within context of the Catchment plan employing consultants, running workshops short courses etc.

About 70 lakh hectare area of the country is affected with salinity and alkalinity. A large area of Uttar Pradesh (10.6 lakh ha.) is also affected with salinity and alkalinity covering 38 districts. Realising the menace of the problem, U.P.L.D.C. (Uttar Pradesh Land Development Corporation) initiated a World Bank sponsored programme sodic Land Reclamation Project in some districts on pilot basis in the year 1993, which was extended later on to 10 districts. This project envisaged to reclaim 45,000 ha land during $1994-95$ to 2000 (Rai et al., 1998).

Similarly, E.E.C sponsored "Alkaline Land Reclamation Project" was started by U.P.L.D.C. in three districts namely Kanpur, Jaunpur, and Unnao during 1993-94.

The above projects have been started with following objectives:

Reclamation of sodic land on large scale for increasing production and environmental substance and developing a model.

Increasing agriculture production and income of villagers living below poverty line.

Effective in a participation of beneficiaries, enhanced co-operation of non-government organisations and strengthening local institutions for effective management of programmes.
Employment generation in undeveloped rural areas.

High value agriculture - orchards, medical plants

Protecting national projects.

Improving environment.

\section{Materials and Methods}

The project is design allowed flexibility to introduce change in the pilot phase based on implementation experiences and increasing farmers participation. The project started in 1993-94 and will be completing seven years in 1999-2000 with a total outlay of Rs.313.71 crore. The project size is limited to the reclamation of about 45 thousand ha over seven years period in 10 districts. The project is administration by Uttar Pradesh Bhumi Sudhar Nigam a U.P. Govt. undertaking.

\section{Results and Discussion}

The resource situation of the beneficiaries was analysed on various parameters which included the possession of land and different other sources including implements etc.

The finding reflected that 28.00 per cent of the beneficiaries were high resource farmers whereas 58.67 per cent were low resource farmers and about 13.33 per cent were landless farmers. The finding lead to conclude that different categories of farmers have been included in the project including landless farmers and the maximum representation have been given to low resource farmers.

The finding reveal that about 35.00 per cent of the total land possessed by beneficiaries fell under problem affected category, of which 25.65 per cent fell under sodicity (Ghanshyam and Prasad, 1985). The finding further reveal that a large area 65.00 per cent 
have been brought under cultivation. These figures are quite high as all the lands before project implementation were lying barren with sodicity and other problems. Some of the residents were inhabited during the project itself and the land was distributed to them.

There are four major sub activities related to land distribution and area planning i.e. land distribution, area planning and developing plant map, land classification and soil testing. The concept of particularly management is so well inherited in the project management that more than 80 per cent of the beneficiaries were found having full involvement in all these four activities which are related to field level planning (Sab, 1999). The participation of local people has been ensured in relation to influencing administration helping the UPLDC workers in approval of site plan, categorization of land by water user groups and collection of soil samples from the field. Based on the findings, it can be concluded that the participation of beneficiaries is of highest level not only in social and administrative aspects of area planning rather it is also ensured in technical aspects also. Therefore, a mechanism has been developed by the project to involve the beneficiaries in all the activities related to area planning.

The beneficiaries were found contributing in management of drainage system. Project officials were found involved in imparting knowledge and providing financial support whereas, beneficiaries were found physically doing the work, arrangement of additional required money and after are of the drainage system. Thus, the project team and beneficiaries were found complimenting each other in the operation and maintenance of drainage systems. 50 to 65 per cent of the beneficiaries were found having full level participation in all the activities except that of management of hume pipes where the full participation of only about 31 per cent beneficiaries was reflected because hume pipe management was more technical than other activities (Mathias, 1995).

\section{Strengths, weaknesses and opportunities of participatory management}

\section{Major strengths of participatory project management being pursued}

The UPBSN programmes have been rated as one of the best in developing countries by visiting Technology Missions of World Bank. These ratings based on certain landmarks achieved in the area of planning borings and link drains together; boring at the highest place with the consent of villagers; farmers involvement in land classification; facilitating group lone, water sharing; helping formulation of water user groups and selfhelp group; scheduled meetings and interaction; suitable drainage avoiding water logging; sharing of input by farmers; strong technical support; increased crop productivity and family income; linkage with different organization; loaning on easily terms; distribution of Panchayat land among poor farmers; NGOs helping in community organization and over and above all existence of transparency in input distribution and benefit sharing (Samuel, 1987).

Resource situation of beneficiaries

\begin{tabular}{|l|l|l|l|}
\hline S. No. & Categories & Number & Percentage \\
\hline 1. & High resource farm households & 42 & 28.00 \\
\hline 2. & Low resource farm households & 88 & 58.67 \\
\hline 3. & Land less farmers (share cropping) & 20 & 13.33 \\
\hline & Total & 150 & 100.00 \\
\hline
\end{tabular}




\section{Resource sitation of beneificaries}

58.67

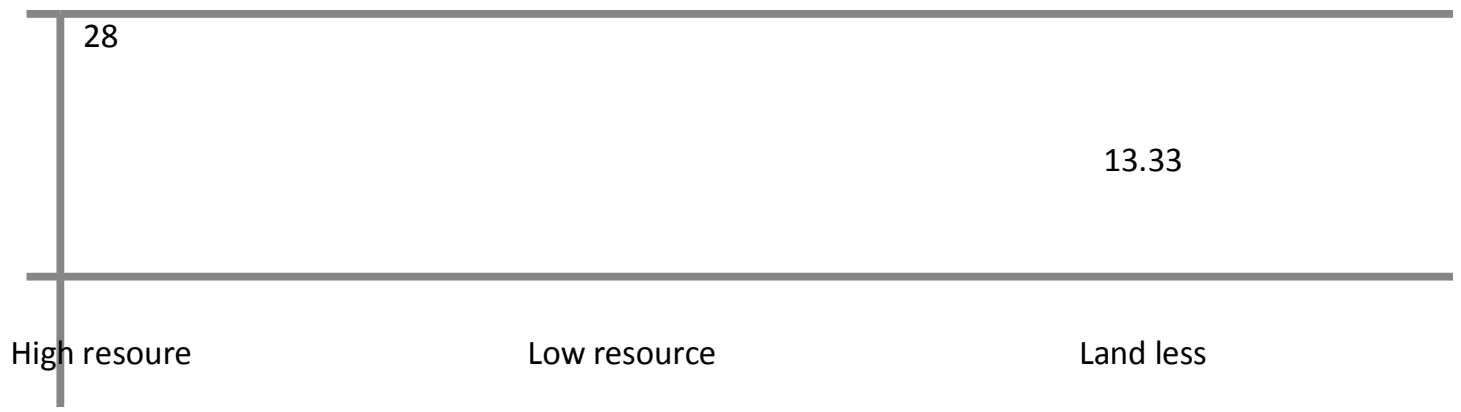

Major soil and water related problems of beneficiaries

\begin{tabular}{|l|l|l|l|}
\hline S. No. & Categories & Affected area (ha) & Precentage \\
\hline 1. & Water logging & 18.37 & 7.72 \\
\hline $\mathbf{2 .}$ & Sodic lands & 60.98 & 25.65 \\
\hline $\mathbf{3}$ & Salinisation & 4.17 & 1.75 \\
\hline & Affected area & 83.52 & 35.13 \\
\hline & Net cultivated & 154.19 & 64.87 \\
\hline & Total area & 237.71 & 100 \\
\hline
\end{tabular}

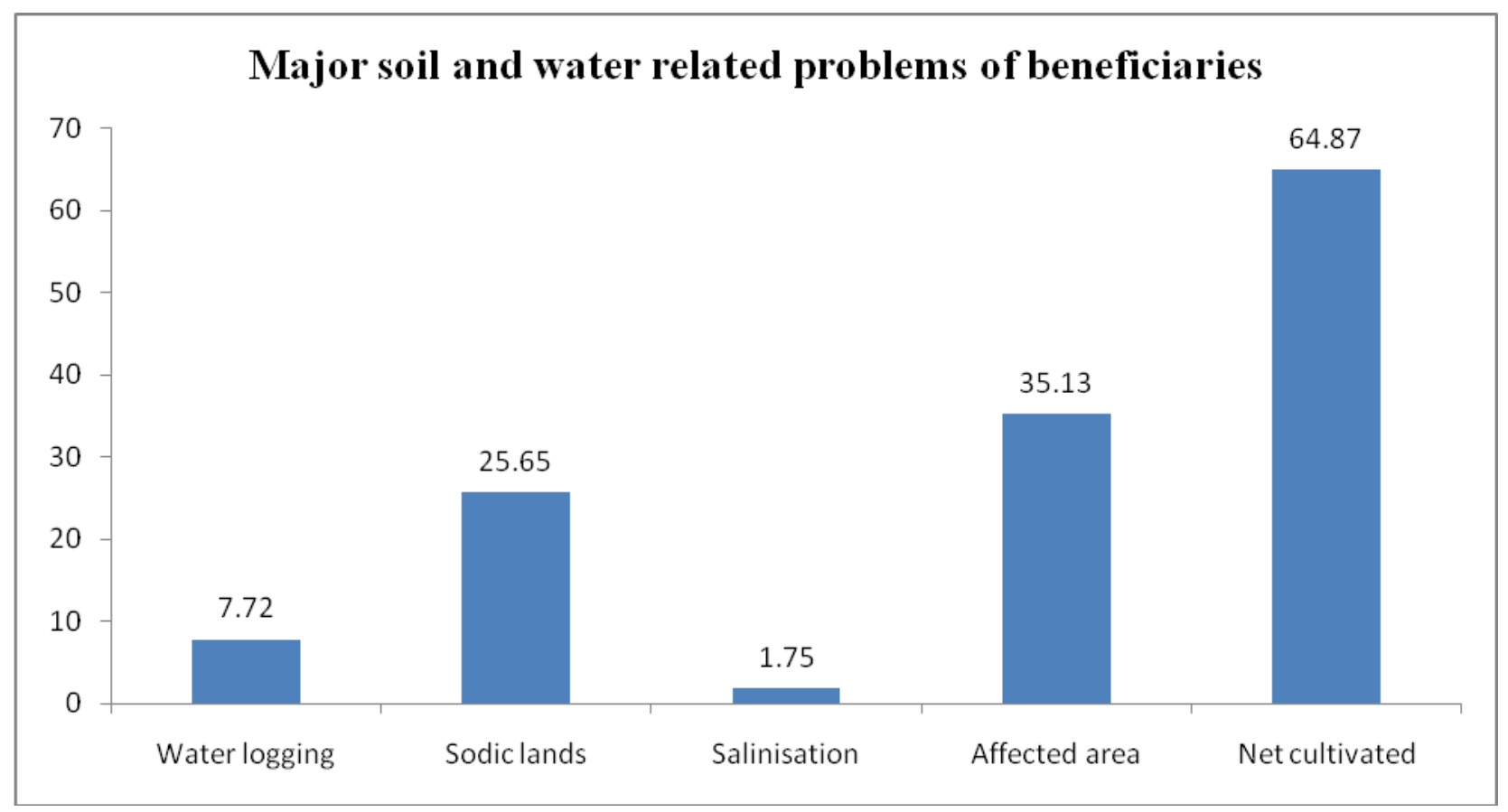


Participation level of beneficiaries in land distribution and area planning

\begin{tabular}{|c|c|c|c|c|c|c|c|c|c|}
\hline \multirow{2}{*}{$\begin{array}{l}\text { S. } \\
\text { No. }\end{array}$} & \multirow[t]{2}{*}{ Particulars } & \multicolumn{2}{|l|}{ Full } & \multicolumn{2}{|c|}{ Partial } & \multicolumn{2}{|l|}{ No } & \multirow{2}{*}{$\begin{array}{l}\text { Mean } \\
\text { score }\end{array}$} & \multirow{2}{*}{$\begin{array}{l}\mathbf{X 2} \\
\text { Value } \\
\end{array}$} \\
\hline & & No. & $\%$ & No. & $\%$ & No. & $\%$ & & \\
\hline \multirow[t]{2}{*}{1} & Land distribution & & & & & & & & \\
\hline & $\begin{array}{l}\text { Pressurize the } \\
\text { administration } \\
\text { through Village } \\
\text { Pradhan }\end{array}$ & 132 & 88 & 11 & 7.33 & 7 & 4.67 & 2.83 & $\begin{array}{l}10.143^{*} \\
\operatorname{Df}=3\end{array}$ \\
\hline \multirow[t]{2}{*}{2} & $\begin{array}{l}\text { Area planning \& } \\
\text { developing plan } \\
\text { map }\end{array}$ & & & & & & & & \\
\hline & $\begin{array}{l}\text { Help the UPLDC } \\
\text { worker for plan } \\
\text { approval in S.I.C. }\end{array}$ & 128 & $\begin{array}{l}85.3 \\
4\end{array}$ & 20 & $\begin{array}{l}13.3 \\
3\end{array}$ & 2 & 1.33 & 2.84 & \\
\hline \multirow[t]{2}{*}{3} & \begin{tabular}{|l|} 
Land \\
classification
\end{tabular} & & & & & & & & \\
\hline & $\begin{array}{l}\text { Categorization of } \\
\text { land by WUGs }\end{array}$ & 132 & $\begin{array}{l}88.0 \\
0\end{array}$ & 10 & 6.66 & 8 & 5.34 & 2.82 & \\
\hline \multirow[t]{2}{*}{4} & Soil testing & & & & & & & & \\
\hline & $\begin{array}{l}\text { Taking samples } \\
\text { from fields }\end{array}$ & 121 & $\begin{array}{l}80.6 \\
7\end{array}$ & 4 & 2.66 & 25 & $\begin{array}{l}16.6 \\
7\end{array}$ & 2.64 & \\
\hline
\end{tabular}

*Significant

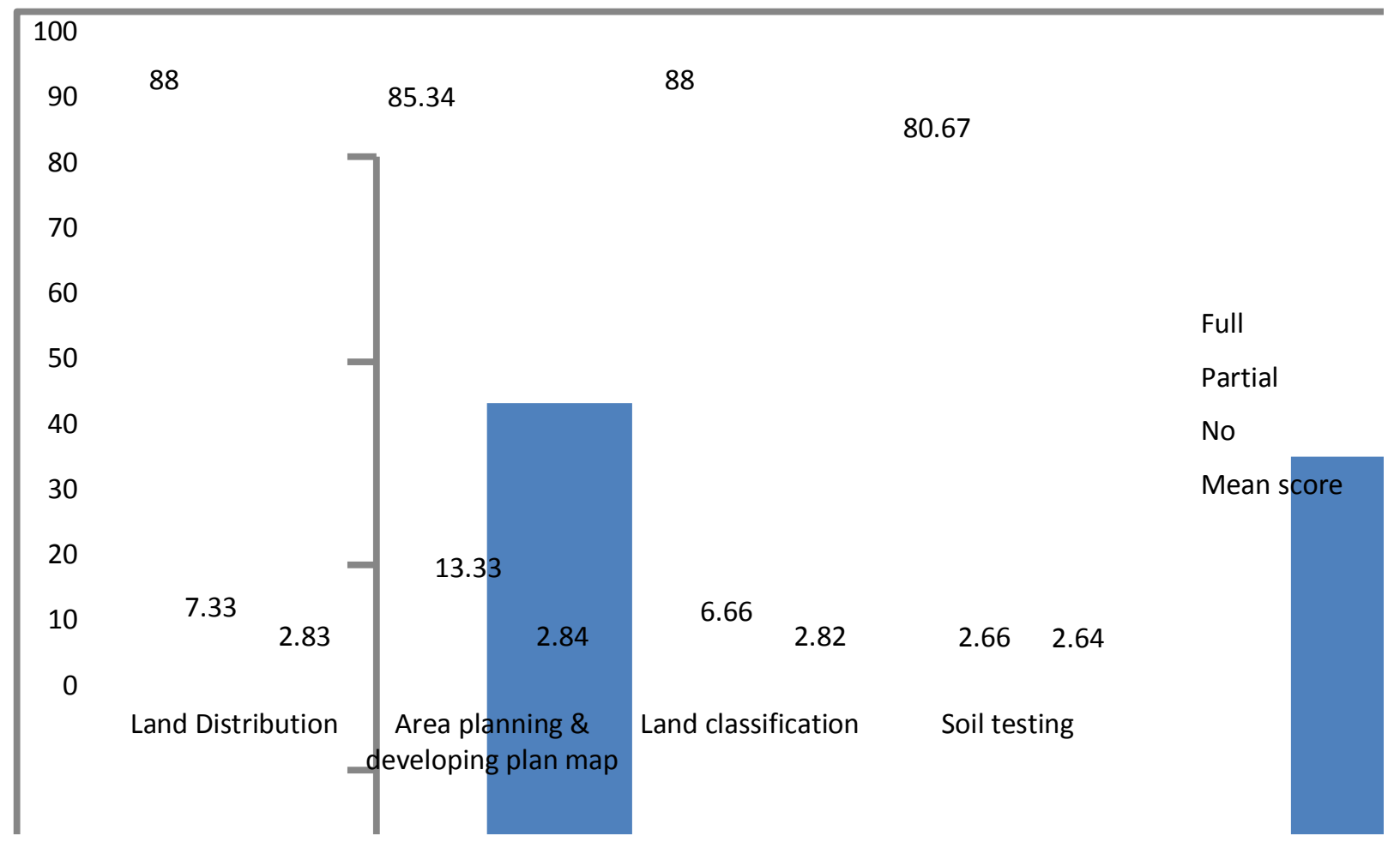


Participation of beneficiaries in management of drainage system

\begin{tabular}{|c|c|c|c|c|c|c|c|c|c|}
\hline \multirow{2}{*}{$\begin{array}{l}\text { S.N. } \\
1 .\end{array}$} & \multirow{2}{*}{$\begin{array}{l}\text { Particulars } \\
\text { Bunding/levelling }\end{array}$} & \multicolumn{2}{|c|}{$\begin{array}{l}\text { Full } \\
\text { No. \% }\end{array}$} & \multicolumn{2}{|c|}{$\begin{array}{l}\text { Partial } \\
\text { No. \% }\end{array}$} & \multicolumn{2}{|c|}{\begin{tabular}{|l|} 
No \\
No. \%
\end{tabular}} & \multirow[t]{2}{*}{$\begin{array}{l}\text { Mean } \\
\text { Score }\end{array}$} & \multirow[t]{2}{*}{ X2 Value } \\
\hline & & & & & & & & & \\
\hline i & $\begin{array}{l}\text { Physically doing } \\
\text { the work }\end{array}$ & 96 & 64 & 44 & 29.34 & 10 & 6.66 & 2.57 & $15.389 * *$ \\
\hline ii & $\begin{array}{l}\text { Arranging } \\
\text { additional } \\
\text { required money }\end{array}$ & 91 & \begin{tabular}{|l|l|}
60.67 \\
\end{tabular} & 47 & 31.33 & 12 & 8.00 & 253 & $\mathrm{Df}=6$ \\
\hline 2. & Field drain & & & & & & & & \\
\hline i & $\begin{array}{l}\text { Physically } \\
\text { making the field } \\
\text { drains }\end{array}$ & 98 & 65.33 & 21 & 14.00 & 31 & 20.67 & 2.45 & \\
\hline ii & $\begin{array}{l}\text { After care of field } \\
\text { drains }\end{array}$ & 89 & 59.33 & 26 & 17.33 & 35 & 23.34 & 2.36 & \\
\hline 3. & Link drain & & & & & & & & \\
\hline i & $\begin{array}{l}\text { Group doing } \\
\text { physical work }\end{array}$ & 84 & 56.00 & 38 & 25.33 & 28 & 18.67 & 2.37 & \\
\hline ii & After care & 78 & 52.00 & 43 & 28.66 & 29 & 19.34 & 2.33 & \\
\hline 4. & Hume pipe & & & & & & & & \\
\hline i & $\begin{array}{l}\text { Arranging } \\
\text { additional money }\end{array}$ & 47 & 31.34 & 15 & 10 & 88 & 58.66 & 1.73 & \\
\hline
\end{tabular}

** Significant

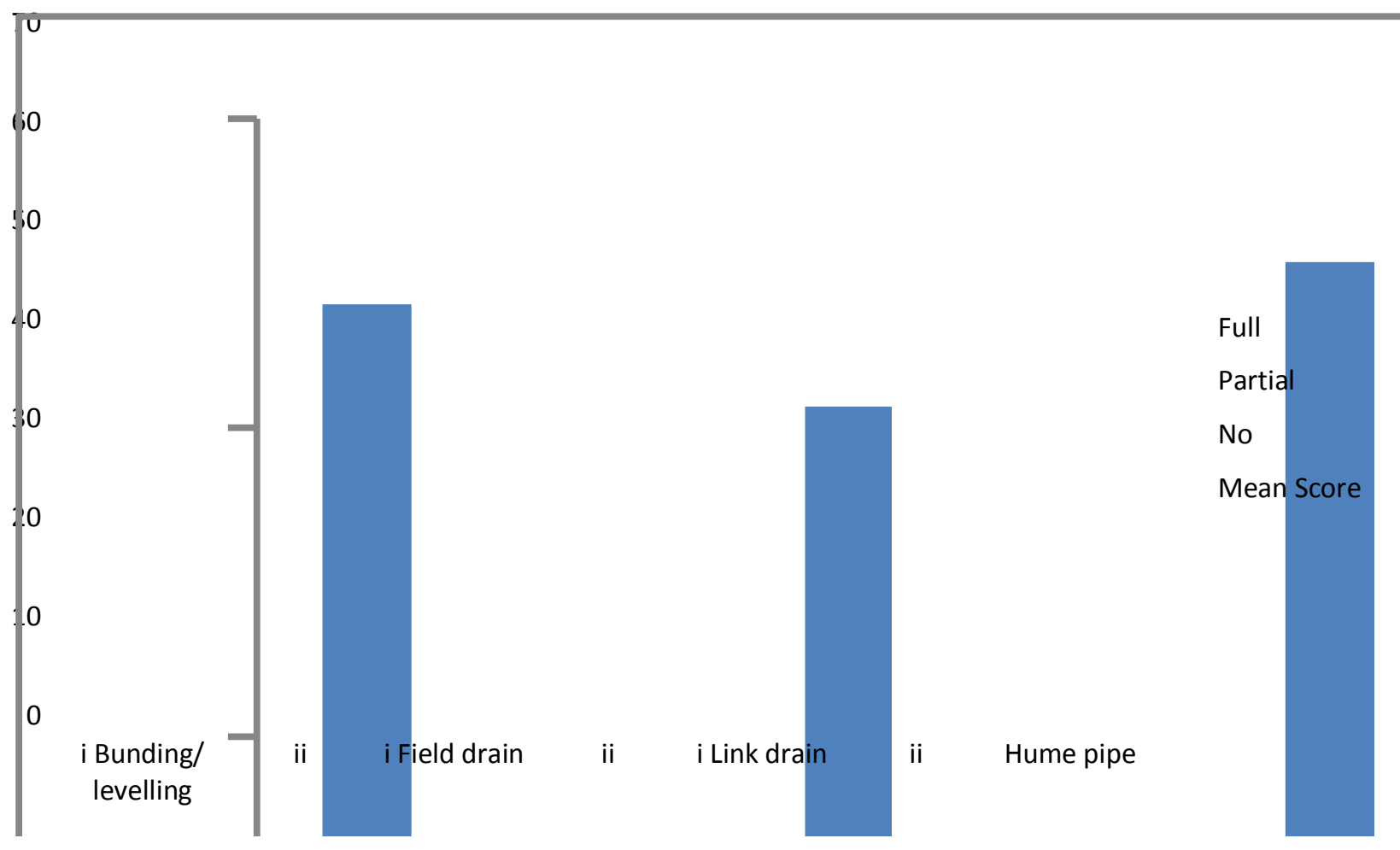




\section{Major strengths of participatory management}

\begin{tabular}{|c|c|c|c|c|c|c|}
\hline S. No. & Particulars & SA \% & A \% & DA \% & Mean score & X2 Value \\
\hline 1. & Link drain and boring are jointly planned & $\begin{array}{l}85 \\
(56.67)\end{array}$ & $\begin{array}{l}75 \\
(30.00)\end{array}$ & $\begin{array}{l}20 \\
(13.33)\end{array}$ & 2.45 & \\
\hline 2. & $\begin{array}{l}\text { Boring at the highest place for facilitating } \\
\text { water availability }\end{array}$ & $\begin{array}{l}82 \\
(54.67)\end{array}$ & $\begin{array}{l}50 \\
(33.33)\end{array}$ & $\begin{array}{l}18 \\
(12.00)\end{array}$ & 2.43 & $16.822 \mathrm{NS}$ \\
\hline 3. & Land classification done jointly & $\begin{array}{l}90 \\
(60.00)\end{array}$ & $\begin{array}{l}46 \\
(30.67)\end{array}$ & $\begin{array}{l}14 \\
(9.33)\end{array}$ & 2.50 & $\mathrm{Df}=15$ \\
\hline 4. & $\begin{array}{l}\text { Farmers become aware about the } \\
\text { characteristics of their lands }\end{array}$ & $\begin{array}{l}72 \\
(48.00)\end{array}$ & $\begin{array}{l}32 \\
(34.67)\end{array}$ & $\begin{array}{l}26 \\
(17.33)\end{array}$ & 2.30 & \\
\hline 5. & $\begin{array}{l}\text { Facilitates group working for sharing equal } \\
\text { water }\end{array}$ & $\begin{array}{l}90 \\
(60.00)\end{array}$ & $\begin{array}{l}38 \\
(25.33)\end{array}$ & $\begin{array}{l}22 \\
(14.67)\end{array}$ & 2.45 & \\
\hline 6. & $\begin{array}{l}\text { Helps in formulation of SHGs for saving } \\
\text { and internal loaning }\end{array}$ & $\begin{array}{l}81 \\
(54.00)\end{array}$ & $\begin{array}{l}44 \\
(29.33)\end{array}$ & $\begin{array}{l}25 \\
(16.67)\end{array}$ & 2.37 & \\
\hline 7. & $\begin{array}{l}\text { Scheduled meetings and interactions are } \\
\text { held }\end{array}$ & $\begin{array}{l}75 \\
(50.00)\end{array}$ & $\begin{array}{l}52 \\
(34.67)\end{array}$ & $\begin{array}{l}23 \\
(15.38)\end{array}$ & 2.34 & \\
\hline 8. & Suitable drainage to avoid water logging & $\begin{array}{l}95 \\
(63.33)\end{array}$ & $\begin{array}{l}40 \\
(26.67)\end{array}$ & $\begin{array}{l}15 \\
(10.00)\end{array}$ & 2.53 & \\
\hline 9. & $\begin{array}{l}\text { Sharing of inputs by farmers for land } \\
\text { reclamation }\end{array}$ & $\begin{array}{l}73 \\
(48.66)\end{array}$ & $\begin{array}{l}47 \\
(31.34)\end{array}$ & $\begin{array}{l}30 \\
(20.00)\end{array}$ & 2.28 & \\
\hline 10. & $\begin{array}{l}\text { Technical support for undertaking various } \\
\text { activities }\end{array}$ & $\begin{array}{l}88 \\
(58.66)\end{array}$ & $\begin{array}{l}44 \\
(29.34)\end{array}$ & $\begin{array}{l}18 \\
(12.00)\end{array}$ & 2.46 & \\
\hline 11. & $\begin{array}{l}\text { Increased crop productivity and family } \\
\text { income }\end{array}$ & $\begin{array}{l}92 \\
(61.33)\end{array}$ & $\begin{array}{l}44 \\
(30.67)\end{array}$ & $\begin{array}{l}12 \\
(8.00)\end{array}$ & 2.53 & \\
\hline 12. & Linkage with different organisations & $\begin{array}{l}85 \\
(56.66)\end{array}$ & $\begin{array}{l}48 \\
(32.00)\end{array}$ & $\begin{array}{l}12 \\
(8.00)\end{array}$ & 2.53 & \\
\hline 13. & Loaning on easy terms & $\begin{array}{l}70 \\
(46.66)\end{array}$ & $\begin{array}{l}52 \\
(34.67)\end{array}$ & $\begin{array}{l}28 \\
(18.67)\end{array}$ & 2.28 & \\
\hline 14. & $\begin{array}{l}\text { Distribution panchayat land among poor } \\
\text { framers }\end{array}$ & $\begin{array}{l}65 \\
(43.33)\end{array}$ & $\begin{array}{l}53 \\
(35.34)\end{array}$ & $\begin{array}{l}32 \\
(21.33)\end{array}$ & 2.22 & \\
\hline 15. & NGOs helping in group formation & $\begin{array}{l}83 \\
(55.33)\end{array}$ & $\begin{array}{l}40 \\
(26.67)\end{array}$ & $\begin{array}{l}27 \\
(18.00)\end{array}$ & 2.37 & \\
\hline
\end{tabular}

SN $=$ Non Significant 


\section{Major opportunities of participatory management}

\begin{tabular}{|c|c|c|c|c|c|c|}
\hline S. No. & Particulars & $\begin{array}{l}\text { SA } \\
\%\end{array}$ & $\begin{array}{l}\text { A } \\
\%\end{array}$ & $\begin{array}{l}\text { DA } \\
\%\end{array}$ & $\begin{array}{l}\text { Mean } \\
\text { score }\end{array}$ & $\begin{array}{l}\text { X2 } \\
\text { Value }\end{array}$ \\
\hline 1. & $\begin{array}{l}\text { Land classification and field survey need to } \\
\text { be conducted more specifically }\end{array}$ & $\begin{array}{l}78 \\
(52.00)\end{array}$ & $\begin{array}{l}54 \\
(36.00)\end{array}$ & $\begin{array}{l}18 \\
(12.00)\end{array}$ & 2.40 & \\
\hline 2. & $\begin{array}{l}\text { Land classification need to be done by } \\
\text { farmers first and then verified by project team }\end{array}$ & $\begin{array}{l}70 \\
(46.67)\end{array}$ & $\begin{array}{l}42 \\
(28.00)\end{array}$ & $\begin{array}{l}38 \\
(25.33)\end{array}$ & 2.21 & $4.603 \mathrm{SN}$ \\
\hline 3. & $\begin{array}{l}\text { Group President and Treasurer need to be } \\
\text { changed on rotation basis }\end{array}$ & $\begin{array}{l}82 \\
(54.67)\end{array}$ & $\begin{array}{l}52 \\
(34.66)\end{array}$ & $\begin{array}{l}16 \\
(10.67)\end{array}$ & 2.42 & $\mathrm{Df}=10$ \\
\hline 4. & $\begin{array}{l}\text { Before taking decisions each group member } \\
\text { need to be taken into confidence }\end{array}$ & $\begin{array}{l}80 \\
(53.33)\end{array}$ & $\begin{array}{l}49 \\
(32.67)\end{array}$ & $\begin{array}{l}21 \\
(14.00)\end{array}$ & 2.39 & \\
\hline 5. & $\begin{array}{l}\text { Developing mechanism for regular cleaning } \\
\text { of link drain }\end{array}$ & $\begin{array}{l}75 \\
(50.00)\end{array}$ & $\begin{array}{l}51 \\
(34.00)\end{array}$ & $\begin{array}{l}24 \\
(16.00)\end{array}$ & 2.34 & \\
\hline 6. & $\begin{array}{l}\text { No barriers between link drain should be } \\
\text { allowed }\end{array}$ & $\begin{array}{l}78 \\
(52.00)\end{array}$ & $\begin{array}{l}54 \\
(36.00)\end{array}$ & $\begin{array}{l}18 \\
(12.00)\end{array}$ & 2.40 & \\
\hline 7. & $\begin{array}{l}\text { Better motivation of group members for } \\
\text { understanding group property as their own } \\
\text { property }\end{array}$ & $\begin{array}{l}72 \\
(48.00)\end{array}$ & $\begin{array}{l}45 \\
(30.00)\end{array}$ & $\begin{array}{l}33 \\
(22.00)\end{array}$ & 2.26 & \\
\hline 8. & $\begin{array}{l}\text { Seed arrangement need to be done at village } \\
\text { level }\end{array}$ & $\begin{array}{l}76 \\
(50.67)\end{array}$ & $\begin{array}{l}46 \\
(30.66)\end{array}$ & $\begin{array}{l}28 \\
(18.67)\end{array}$ & 2.32 & \\
\hline 9. & $\begin{array}{l}\text { Enhancing repayment of loans by group } \\
\text { member }\end{array}$ & $\begin{array}{l}81 \\
(54.00)\end{array}$ & $\begin{array}{l}44 \\
(29.33)\end{array}$ & $\begin{array}{l}25 \\
(16.67)\end{array}$ & 2.37 & \\
\hline 10. & Regular screening of defaulters & $\begin{array}{l}73 \\
(48.67)\end{array}$ & $\begin{array}{l}40 \\
(36.67)\end{array}$ & $\begin{array}{l}37 \\
(24.66)\end{array}$ & 2.24 & \\
\hline 11. & $\begin{array}{l}\text { Draining out salt affected water to distant } \\
\text { place linking to some water source }\end{array}$ & $\begin{array}{l}75 \\
(50.00)\end{array}$ & $\begin{array}{l}53 \\
(35.33)\end{array}$ & $\begin{array}{l}22 \\
(14.67)\end{array}$ & 2.35 & \\
\hline
\end{tabular}

The mean value showing level of opinion of beneficiaries between a minimum of 2.22 to 2.53 out of 3.00 exhibit percentage agreement to the tune of 74.00 to 84.33 per cent. Thus, the finding indicate that the approaches like group working, water sharing, like drain and boring development for irrigation and leaching, linkage with different oragnisations and transparency in all the activities are the major strengths contributing to the success of this project.

\section{Major opportunities in the participatory project management}

The highest opinion was received for conducting specific land classification and changing office bearer of groups on rotation basis. These two factors are the base for different kinds of works to be under taken in the project. Land classification decides the kind of subsidies to be provided by the project to beneficiaries and also other kinds of supports like technical input and other supports. Link wise group is the operational unit which holds the responsibility of looking after most of the project activities. Therefore, the members of such groups feel that Group President and Treasurer should be changed regularly on a rotation so as to avoid dominance of certain people and also for the proper functioning of the group with equal participation of all the group members.

The other important opportunities like "Developing mechanism for regular cleaning of like drain" developing understanding among group members for owning group property, "arrangement of seed at village level", "enhancing repayment of loans", regular screening of defaulters" and "properly draining out salt affected water. 
FAO's Agricultural Extension manual offers the following recommendations on how farmer participation might be achieved. Farmers are more willing to participate in activities which meet their felt needs and priorities which can be determined through a quick needs assessment. The needs of all people should be taken into consideration, not just those who are accessible and co-operative. If farmers are encouraged to express their needs and provide some input into the structure of project/programme, they should not be ignored. Farmer's ideas must be taken into account to sustain their involvement. Farmers are more likely to participate if actual benefits are directly tied to participation (Khatik et al., 1997). Farmers especially those with low incomes, are more likely to participate and remain involved if the benefits are material, direct and immediate. One of the best ways of getting farmers interest is through the use of convincing and demonstrations and trials.

Uttar Pradesh Land Development Corporation also known as UPBSN (Uttar Pradesh Bhoomi Sudhar Nigam) is running land reclamation programmes in 15 districts of Uttar Pradesh including district Kanpur Dehat and Kanpur City since 1994. This study has been conducted in the project unit-I operational in district. Kanpur Dehat and Kanpur City with a purpose to find out the participatory management mechanism followed in the project by way of involving various levels of officials responsible for project implementation and also the beneficiaries playing the role of equal partners in the implementation of various activities. Thus, the study besides, including project official as respondents, includes beneficiaries also as respondents. In total sixty two (62) field funcationaries and 150 beneficiaries have been interviewed in order to find out the level of involvement in various agricultural activities related to project management. As Kanpur unit-
I happen to operate mainly in district Kanpur Dehat and in some parts of district Kanpur Nagar, district Kanpur Dehat and Kanpur Nagar become the ultimate investigation areas for this study. Out of the five sub units, operational in block Maitha and unit-III in Shivrajpur were selected on random basis for the study. From sub unit-I four villages were selected on random basis. Further, it was taken care to select one village purposively from each sub unit from where the project has been withdrawn so to study the withdraw strategy pursued by the project in such villages. Thus, a total of 10 villages were selected for investigation.

\section{References}

Ghanshyam and Prasad, R. 1985. "Farmers Response to Amendment Use for Reclaiming Alkali soils and use of sodic waters for Crop Production". India Journal of Extension Education. IJEE Vol. XXXI. No.1-4.p (18).

Khatik, G.L., Kumar U. Singh, H.B. and Pande, V.C. 1997. "People's Participation in Soil and Water Conservation Programmes in Mahi Ravines"ISEE.pp.67.

Mathias, 1995. "Indigenous knowledge and participatory technology development". Extension Digest. Vol.3:10.

Rai, R.N., Singh, K.P. and Prasad, R. 1998. "Experiences on some watershed based Operational Research Projects of Uttar Pradesh for Watershed Land Development" Waste Land Development, Challenges and Opportunities. C.S.A.U \& T. Kanpur. pp.15.

Sab, A.K., 1999. "Participatory Development Concept need and Psychology" Journal on Rural Development.pp.31.

Samuel, Paul 1987. Community Participation in development project". Washington D.C. the World Bank Report 9:143.

\section{How to cite this article:}

Arvind Kumar Singh, A.K. Singh, Anurag Singh and Rajmani. 2017. Participatory Management Issues in U.P. Alkaline Land Reclamation Project. Int.J.Curr.Microbiol.App.Sci. 6(9): 1442-1450. doi: https://doi.org/10.20546/ijcmas.2017.609.175 